\title{
The Jordanian Legal Regulation for Implementing the Arbitral Award as an Executive Bond in accordance with the Jordanian Execution Law No. 25 of 2007
}

\author{
Shams El-Din Qassem Al-Khazaleh ${ }^{1}$ \& Sayel Mofleh Momani ${ }^{1}$ \\ ${ }^{1}$ Irbid National University, Irbid, Jordan \\ Correspondence: Shams El-Din Qassem Al-Khazaleh, Irbid National University, Irbid, Jordan.
}

Received: January 5, 2018

Accepted: February 21, 2018

Online Published: November 30, 2018

doi:10.5539/jpl.v11n4p109

URL: https://doi.org/10.5539/jpl.v11n4p109

\begin{abstract}
The implementation of the arbitral award is the final stage of the arbitration process, which is the substance of the arbitration agreement, since the control is based on the principle of the authority of the administration and as it is the focus of this research, the arbitration judgment, as well as the implementation of the arbitral award, will be discussed in addition to the terms of the enforceable judgment, as well as judicial control over the execution of the award to reach the result that the legislator was not successful in organizing methods of appeal by arbitration.

The Jordanian legislator adopted the broad concept of executive bonds and then not limited to judgments and decisions, but included official and ordinary bonds and tradable commercial papers. The executive bonds are the documents specified in the law of enforcement or any other law and are the reason for establishing the right to implement execution and Article 6 of the Jordanian Enforcement Law referred to this. In addition, the Jordanian Arbitration Law No. 31 of 2001 approved the implementation of the arbitrators' judgments if the court ruled to uphold these provisions.

The focus of our study was to implement the arbitral award as an executive bond and for its specificity as a judgment issued by natural persons with no jurisdiction. Only derive their task from the will of individuals. The parties to the dispute, but the reality that made the arbitration at the present time of the features that make it more acceptable by individuals to settle their disputes from resorting to the jurisdiction of the state, and respect for the legislator and his quest for stability and security made those decisions executive bonds under certain conditions are implemented through them. It is on this basis that this study is divided into sessions and we will address the concept of arbitral award. Then the implementation of the arbitration award and then we will discuss the terms of the arbitral award and enforceable judicial control over it and then move to the conclusion and its recommendations.
\end{abstract}

Keywords: legal regulation, arbitral award, executive bond, Jordanian execution law

\section{Introduction}

It is known that the Jordanian legislator has decided several ways to resolve disputes in society. One of the most important ways to settle disputes in Jordan is to sue in the courts, which are defined as the official path of the state as a general rule. The judiciary is often overcrowded with issues and disputes that affect the quality of the courts' work. There is always talking of a slow process of litigation and delays in the collection of rights by the litigants to the rights that have been established by their substantive laws ${ }^{1}$. Such an act has led States to recognize other ways of resolving disputes necessitated by practical and logical imperatives. These other methods have been labeled by law scholars as "alternative methods of dispute resolution". It has been named because it is an alternative to litigation. One of the most important of these methods is to resort to arbitration. ${ }^{2}$

In this context, arbitration is generally defined as a conventional dispute resolution method in which a person other than the litigants issues an enforceable judgment of the dispute to the litigants through legally prescribed

\footnotetext{
${ }^{1}$ Jamal, M. \& Okasha, A. (1998) Arbitration in International and Domestic Private Relations, Halabi Publications, Beirut, Vol. 1, pp.60

${ }^{2}$ Al-Sawy, A. (2002) Arbitration in accordance with Law No. 27 of 1994 and International Arbitration Regulations, Don Publisher, pp. 95 et seq
} 
procedures or agreement as permitted by law $^{3}$. The Jordanian legislator has decided to regulate matters related to arbitration in a special law, Arbitration Law No. 31 of $2001^{4}$. As is clear from the above definition of arbitration, it is arbitration as a legal system that seeks to resolve the disputes that are being dealt with. The outcome of the arbitration is called arbitral award, where this provision is a decision of rights and binding on the opponents subject to it. And once the opponent has obtained the right to an arbitral judgment in his interest, this provision has no benefits and cannot achieve the goal only by the implementation of the other opponent to what came in it. The issue of the implementation of arbitral awards is very important. Implementation may be voluntary by the sentenced person of his or her own free will. In the event that the intention for the voluntary execution of the convicted person fails and fails to do so, the will of the debtor shall be enforced. ${ }^{5}$

The issue of the implementation of arbitral awards is crucial to arbitration as a settled dispute resolution process. Where the mechanism of implementation of judgments is flawed, or there is a defect in the organization of the implementation of the result of arbitration, which may make opponents for the collection of efforts and expenses are not negligible, This would prompt the opponents to refrain from, or to reduce the resolution of, their disputes through arbitration; hence, this study concerned the mechanism for the implementation of arbitral awards under the arbitration law to deal with most issues related to the subject matter of arbitration.

The issue of the mechanism for implementing arbitral awards under the Jordanian Arbitration Law represents the problem that the research intends to address. The research presents an analytical study that contains a detailed assessment of the position of the Jordanian legislator on this subject, where the extrapolation of the said arbitration law found that the Jordanian legislator recognized arbitration as an alternative way to settle disputes. However, it states that it is not possible to implement the arbitration result out of the will of the convicted person except by following an exclusive route that entails several procedures ending with a judicial decision authorizing such execution. As well as the existence of legal provisions relating to the subject of implementation of arbitration provisions in the core of this law, i.e., the Arbitration Act requires reorganization to reach greater clarity and fairness. It should be noted here that the problem dealt with by this research has not been put forward at this level of detail and analysis in Jordanian law. The researcher came up with results that were first presented at this level of the statement and clarification.

\subsection{Research Purpose}

The focus of this study is to implement the arbitral award as an executive bond and for its specificity as a judgment issued by natural persons with no jurisdiction. Only derive their task from the will of individuals. The parties to the dispute, but the reality that made the arbitration at the present time because of its advantages that make it more acceptable by individuals to settle their disputes from resorting to the jurisdiction of the state, and as a respect from the legislator and his quest for stability and security he made those decisions executive bonds implemented under certain conditions. On this basis, this study was divided into topics, in the first requirement it deals with "The concept of arbitral award", then in the second requirement it deals with "the implementation of the arbitral award" and in the third requirement it discusses "the terms and conditions of the enforceable arbitration judgment" and then moves on to the conclusion, and its recommendations.

\subsection{Research Problem}

This paper deals with the subject of the mechanism of implementation of arbitral awards in the Jordanian Arbitration Law. It deals with the research of a subject to be treated for the first time with such theoretical and practical detail that interested researchers and dealers under the Jordanian Arbitration Law. The importance of this issue stems from the importance of arbitration, which represents an alternative way of litigation to settle disputes. The implementation of the arbitral award is the main objective that the adversaries seek when using this legal means to resolve disputes. This study, which dealt with the subject of the implementation of arbitral awards in the Jordanian Arbitration Law, found that the Jordanian legislator decided that once the convicted person is prevented from voluntarily implementing the arbitration judgment and the convicted person wishes to execute it through the enforcement services, the debtor must resort To the Judiciary to give the arbitral award the power necessary for execution. In the sense that it is necessary to resort to the judiciary following certain procedures to make the arbitration provision an executive bond respected by the public authority responsible for implementation. The proposed procedures have been presented and evaluated legally for this subject, and concluded that the legislator should reorganize this subject in order to achieve greater health and justice.

\footnotetext{
${ }^{3}$ Hassan, A. (2001) Optional and Compulsory Arbitration in Civil and Commercial Disputes, University Thought House, Alexandria, pp. 11

${ }^{4}$ the Official Gazette, Published on page (2821) of No. 4496, dated 16/7/2001.

${ }^{5}$ Aboudi, A. (2005) Explanation of the provisions of the law of implementation, House of Culture, Amman,
} 


\subsection{Research Question}

The study seeks to answer the following question: whether the Jordanian legislator in the arbitration law through the provision of Article 54 concerning the appeal of the arbitral award, bringing justice between the parties to the arbitration contract?

\section{Methodology}

In order to answer the question, the researcher followed the analytical and comparative method of the relevant laws to solve the problem. The Plan of study was to implement the arbitration award as an executive document

\subsection{Implementation of the Arbitration Award as an Executive Bond (The Essence of Enforceable Arbitration Judgment)}

The term arbitral award is often used to denote the final decision of the arbitral tribunal to adjudicate the subject matter of the dispute presented to it, and it is referred to as the final arbitration award for the dispute or final award. This judgment is rendered by the arbitral tribunal on the merits of the allegations presented to it and the rule of law is applied to it with a view to resolving the dispute between the parties to the arbitration dispute in a final manner ${ }^{6}$.

In addition, the arbitral award has the characteristics of the judicial judgment issued by the judiciary, which has the authority of the order and is enforceable subject to the provisions of the law, since it cannot be challenged by any of the usual means of appeal such as appeal, as well as unusual methods of appeal such as re-trial or the objection of others.

It should be noted that these advantages of an arbitral award make it separate from the control of the state's jurisdiction. The arbitral award issued by the arbitrator and based on the exclusive competence of the parties to authorize an ordinary person not to be in charge of the power to adjudicate disputes by virtue of the nature and description of the judicial judgment cannot remain isolated from the control of the state judiciary ${ }^{7}$.

A judicial ruling issued may be a decision or a judgment of origin or a judgment of obligation ${ }^{8}$.

Thus, the arbitral award is not a judicial judgment, although a judgment is an arbitral award but before it is arbitral, which means that denying the judicial nature of the arbitral award is not a denial of the nature of the arbitration or of its procedural nature as a judgment. That is not to deny his character as a judge ${ }^{9}$.

This ruling was singled out by the laws in its own way, which does not negate its status as a judge, but it is distinguished from the judicial acts, whether they are judgments or judicial orders, especially the judicial rulings of its various jurisdictions. This means that the arbitral award is historically superior to the judicial ruling, since it is recognized that arbitration is earlier in existence than the judiciary, which means that the arbitral award is historically superior to the judicial ruling, and before the appearance of the judiciary, the arbitral award would take the idea of judgment. After the appearance of the judiciary, neither the arbitration judgment take the idea of judgment, nor the judgment takes the idea of judgment, since the arbitral award is an arbitral judgment and the judgment of the judiciary is judicial.

\subsection{Implementation of the Arbitration Award}

The implementation of the judgment whatever the nature of this provision is the goal of the trial and the motivation for the rivalry and tries to win the most gains so the moment of implementation can be considered the highest summit of the arbitration dispute where there is nothing after that.

So, the implementation of the arbitral award is the final stage of the arbitration process as a whole and is the only way to prove the rights in the hands of the owners and to implement their obligations voluntarily through voluntary implementation which is the general origin, or through forced execution if the ill-intention of one party is recognized by the public authority, in this case needs to be ratified or ordered to be implemented, because there is no source of authority, because it is an interim authority due to its contractual origin ${ }^{10}$. Although the will of the litigants is the basis on which the arbitration provisions are based, they cannot, however, to provide that

\footnotetext{
${ }^{6}$ Tarawneh, M. (2010) The Judicial Supervision of Arbitral Jurisdictions in Jordanian Law, Comparative Study, 1st edition, Da'ir Wael for Publishing, p. 43 et seq.

${ }^{7}$ Haddad, H. (2000) Supervision of Arbitration Rulings between Duality and Unity, Dar Al-Fikr Al-Jami` for Publishing, Alexandria, issue, 26 and beyond

${ }^{8}$ See the text of Article 40 Jordanian Law No. 31 of 2010

${ }_{9}^{9}$ Abu Al-Wafa, A. (1978) Mandatory Compulsory Arbitration, issue, 3, p. 245.

${ }^{10}$ Shehata, M. (1993) Establishment of the Convention for the Judicial Authorities of the Arbitrators, pp. 15-19.
} 
such provisions with the executive force which allows for the forced implementation of the obligations contained therein ${ }^{11}$ because those who do the job are not public officials have the authority to order. This will be clarified through two requirements:

\subsubsection{Optional Implementation}

Optional implementation is the natural way to implement an arbitral award. This is the case with most arbitral awards, which are implemented voluntarily without the intervention of the public authority to obtain the execution order, except for the privacy of arbitration based on trust and respect for the principle of good faith as well as private contracts. It draws the power of implementation from respect for the principle of good faith.

While we recognize that the contract is the law of the contracting parties, and it is necessary to implement the effects that may result from the contract sometimes to adhere to the contract, and try to exaggerate to benefit from it at the expense of the other, to choose from the implementation of the most unfair, no doubt that this behavior is rejected by the rules of ethics and justice ${ }^{12}$. Therefore, Article 148/1 of the Jordanian Civil Code stipulates that: (It must be carried out in accordance with what it includes and in a manner that is spent with good intention ${ }^{13}$. It is intended that the contract should be executed in good faith, with due regard to ethics, honesty, intent and moderation in the implementation of the contract so that this implementation does not overturn.

The principle must prevail contractual relations and is the source of force binding to the contract as dealing with honesty and integrity and honor with others in a manner that keeps the exercise of the right within the objectives of the useful and fair for which it was established and committed by both parties of the contract where this practice does not cause harm to others without a legitimate reason, but help every individual who has a right to reach his right. When two parties to the contract commit themselves to certain obligations, they seek to achieve a mutually beneficial goal and they agreed to this end, and the means to achieve them are committed to these means, and therefore their commitment is the source of the executive force of the contract because it stems from the will to implement a very useful inquiry for both parties. If the will to implement the purpose of the abuse of the method of the nodal to differ significantly from those that were desired at the conclusion of the contract, the judge intervenes to prevent the abuse of executive power of the contract to achieve goals other than those that he has identified, and the parties have agreed upon when concluding. Hence, it is true that the executive power of the contract follows the principle of good faith on which contractual relations must be based. This principle is legally incorporated into the legal system of the contract and not only a changing reality that cannot be adjusted to change with the circumstances of each case ${ }^{14}$. This principle has become one of the general principles of the law, which stipulates that the parties must abide by the integrity of the contract and hold them responsible for non-implementation and compensation for any damage to the victim's loss and loss of profits ${ }^{15}$.

It is clear from this that arbitration based on its convention is carried out optionally, in line with the will of the parties that have accepted the will to execute from the outset, otherwise it would be bad faith that is contrary to the principle of good faith that should prevail in contracts as in this case we do not have arbitration in the strict sense which must be interpreted on the basis of the principle of trust in dealing.

\subsubsection{Compulsory Execution}

The arbitration rule should be executed with the consent of the parties, in line with the will to implement, which was agreed upon in advance, since the violation of this is contrary to the principle of good faith on which the transactions are based, which requires issuing an order of execution from the competent court because the source of the decision lacks the power of the matter and the source of its authority is the agreement of the parties, not the state, as the judge for possible implementation.

Article 53/ of the Jordanian Arbitration Law provides that: request for the execution of the Arbitral award shall not be accepted if the date of the action for nullification of the award is not completed.

It is clear from the above text that the period of application for an arbitral award is thirty days from the date of the notification of the arbitral award to the convicted person, explicitly the text of Article 50 of the Jordanian

\footnotetext{
${ }^{11}$ Al-Tahtawi, M. (1999) Arbitration in Civil and Commercial Materials and its Permissibility in Administrative Contract Disputes, no edition, New University Publishing House, Al- Alexandria, p 214.

${ }^{12}$ Al-Hakim, A. (1993) Al Kafi to explain the Jordanian and Iraqi law in the obligations and legitimate rights, p. 508, unpublished

${ }^{13}$ Ibid. P. 508

${ }^{14}$ Al- Auji,M. (1996) Civil Law Vol.1, Bassoun for Publishing and Distribution, Beirut - Lebanon, $1^{\text {st }}$ edition, p. 114.

${ }^{15}$ Tarawneh, M. (2001) The Reform of International Trade Law, An Analytical Study of the Law of International Trade, and its Relation to Private International Law, Dar Rand for Publishing and Distribution, $1^{\text {st }}$ edition, p. 91.
} 


\section{Arbitration Law ${ }^{16}$.}

\subsubsection{The Most Important Conditions for Compulsory Implementation}

- Compulsory execution shall not be limited to a lawful decision: This condition requires that the employees required to use the general force for its implementation shall be lawful. The material force may not be used to carry out an illegal proceeding, regardless of whether that decision is applied in a legislative text The decision of control shall mean that the individual determination is not required to be written and published, which may be oral.

- There shall be resistance to the implementation of the decision of seizure. This entails an obligation on the party of control to direct the concerned party to the optional implementation first, giving him a reasonable opportunity for voluntary implementation before moving to the use of force.

- The compulsory execution shall not be limited to what is necessary to avoid the impending danger arising from the non-enforcement of the decision of seizure. The administrative judge shall supervise the completion of the precedent when the appeal is considered to be exceeding authority. The administrative judge shall cancel the work carried out by force.

\subsection{Conditions of Arbitration and Judicial Supervision}

The conditions for the execution of the arbitration award are related to compulsory implementation and not to optional implementation. The legislator has considered it to be a public order, so it cannot be waived or to agree to that, where the legislator must certainly make sure that the court is available for public order.

\subsubsection{Conditions of Arbitral Award}

Article 53 states:

a) A request for invalidity of an arbitral award shall not be accepted if the date of raising a case for nullification of the judgment has not been ended.

b) The application for execution shall be submitted to the Court together with the following:

1) A copy of arbitration agreement.

2) A copy of the arbitration or a signed copy of it.

3) A translation of an arbitral award certified by an accredited body into Arabic if that award is not made.

While Article 54/states that the competent court shall consider the application for execution and shall order its execution unless it is found that:

1) That this award includes what is contrary to the public order in the Kingdom and if it is possible to split the award in the violation of public order, the order to implement the rest.

2) That the convict has not been properly informed.

3) It is not permissible to appeal against the decision of the court issued by the order to implement the arbitration award, while the award issued against the execution of the application may be appealed in front of the Court of Cassation within thirty days from the day following the notification, consequent the ratification of the decision issued by the order to implement the fall of the arbitration agreement.

\subsubsection{Judicial Control of the Execution of the Arbitral Award}

Judicial supervision of the arbitral award does not raise any problems, in the case of the judicial unit, in which the arbitral award is challenged by invalidity by the convicted person and the judiciary, which is required to order the execution by the convicted person in his favor, since it is inconceivable that the judge will rule on the nullity of the award, and then issue an order to execute it after this judgment nullified ${ }^{17}$.

The Jordanian legal system adopts the principle of judicial supervision over the arbitration award through the Court of Appeal. Article 54 of the law stipulates that the applicant must submit his application in the form of a summons, not a case law. This requires that the proceedings be routine. The state is based on this summons, and it is condemned by an examination, and this is benefited from the provisions of the Arbitration Law, so that there is no objection, no award, and no methods of appeal such as those decided by the legislator against the awards. Accordingly, the Court either orders or rejects the application without being subject to the legal basis of the case submitted to it. It does not stipulate, but rather ascertains that the conditions required by the legislator are

\footnotetext{
${ }^{16}$ Articles 53 / A, 50 Jordanian Arbitration.

${ }^{17}$ See Haddad, H. (2000), Op. p.6.
} 
available and that there are no impediments to implementation ${ }^{18}$.

\subsubsection{The Role of the Judiciary in the Adoption of the Award}

If the proceedings of the arbitration case are completed and the prosecution is closed and the parties to the dispute no longer have what they have to offer in respect of the case, the case is closed when the case is scheduled to be adjudicated. The arbitrator must adjudicate this case and he may not delay it for any apparent reason. At the time specified in the arbitration document, unless the parties specify in the arbitration document a period of judgment, the arbitrators shall issue their judgment within ninety days from the date of the decision to adopt the arbitration document. If this is not achieved, the litigants may submit the matter to the judicial authority originally competent to consider the dispute To decide on the matter and the order to terminate it or extend the date for another period beyond the prescribed period beginning 31, the judicial body shall have the right to directly supervise the report to increase the period prescribed for consideration of the case or not.

When the judgment is issued by the arbitral tribunal, whether this judgment is the final judgment or was related to the implementation of a procedure of the proceedings, it must be filed within five days with the judicial authority originally competent to consider the dispute, and the parties are informed of this deposit. The litigants may submit their objections to the arbitrators to the party to whom the judgment was filed within fifteen days from the date of their notification to the arbitrators. If they do not submit such objection within this period, this deposition became final.

If they submit their objection to the judicial authority originally competent to hear the dispute during this period, this judicial body shall consider their objection and decide to reject this objection and issue the order to execute the judgment or accept the objection submitted by the litigants and settle it in a manner that terminates the dispute. The time limits prescribed by the judicial authority, which is originally competent to consider the dispute, shall be final.

The judgments issued by the arbitrator are judicial judgments that have the force of judgments issued by the general public court. A document containing the contents of the general judicial documents shall be drawn up from the summaries of the statements of the litigants, their documents, the reasons for the sentence, its operative date, and the signatures of the arbitrators, and if one or more of them refused to sign the judgment, it shall be proved in this document. The judgment document shall also include the names, date of issue, venue, subject matter, names of the arbitrators, their fees, their names and their respective employees, attendance and absence, and a record of the facts of the case, their applications and a brief summary of their arguments and substantive defense. Then the reasons for the decision and the operative and the arbitrators and the writer sign the copy of the original decision containing the above and be kept in the file of the lawsuit within seven days of depositing the draft, and after the release of the judgment document the verdict shall be pronounced in the presence of the arbitrators or their representative, the judicial authority originally competent to the judgment after its issuance in terms of the order to explain or correct this provision in addition to the submission of one or both parties this matter.

The arbitrator shall make the necessary amendment to the original copy of the judgment. If the arbitrator is not persuaded to make the amendment, he shall make such a decision as is the case in all judicial proceedings, and such interpretation shall be complementary to the basic provision and not contrary to its apparent meaning.

If one of the litigants is not satisfied with this interpretation, he may submit to the competent judicial body the dispute to hear the objection. This shall apply to the incomplete judgment and the arbitrator shall be required to complete the shortfall if the judgment does not cover all parts of the case brought before it. The competent judicial authority shall also consider the manner in which the objection is to be submitted by the litigants or one of them in respect of the non-conviction of the judgment. The objection shall be accepted if the objection is submitted to this judicial body within 15 days from the date of informing the litigants of the ruling, if he does not proceed during this period, the judgment is final.

If the judgment is completed, the judicial authority competent to consider the case must first accept the judgment and submit it to it and include it in the case file, and then issue the order that it must be executed when the judgment becomes final

\section{Conclusion}

After reviewing the main aspects of this study and clarifying how the execution of arbitral award is implemented through the optional implementation as the basic rule and the resort to forced implementation, which was

\footnotetext{
${ }^{18}$ See Tarawaneh, M. (2001) Op. Cit., P. 285 Et seq
} 
discussed and studied through the time of implementation, as well as judicial control of this award and accepted the statement of the concept of arbitral award and then to our view of the opinion to note if the legislator implemented his texts to achieve justice and this opinion is:

The provisions of article 54 of the Arbitration Law shall be deemed to be the leave to challenge the decision of the Court of Appeal to order the execution in front of the Court of Cassation and to prevent it from challenging the decision to order the implementation, so that it should have made the appeal permissible, whether it was rejected or accepted by the Court of Cassation or the separation of the decision issued by the Court of Appeal final.

It is noticeable in the current era if the reality of the resolution of disputes in the internal and international spheres where the formal judiciary and the arbitration are intended to promote the same judicial function and the same tools and procedures almost, the attraction continues between them both on the one hand to take the formal judiciary method of arbitration based on flexibility and speed and confidentiality, or the arbitration take the formal elimination tools on the organizational and procedural level.

The judiciary assists arbitration, and its assistance is conditional on the fact that there is no such thing as public order and the judge is considered a guardian of public order in his country.

Arbitration in turn helps the judiciary and eases the burden on it in resolving disputes that, without arbitration, would have weighed heavily on the judiciary. Consequently, the prevalence of a culture of arbitration would have positive repercussions on good judicial administration, reducing the number of cases in front of the courts and raising the level of judges. The similarity of the mechanisms of dispute resolution in front of the courts and in front of the arbitration has brought them closer to a common formula for settling these disputes

\section{References}

Aboudi, A. (2005). Explanation of the provisions of the law of implementation. House of Culture, Amman.

Abu Al-Wafa, A. (1978). Mandatory Compulsory Arbitration, issue, 3, p. 245.

Al- Auji, M. (1996). Civil Law Vol.1, Bassoun for Publishing and Distribution, Beirut - Lebanon, 1st edition, p. 114.

Al-Hakim, A. (1993). Al Kafi to explain the Jordanian and Iraqi law in the obligations and legitimate rights, p. 508, unpublished.

Al-Sawy, A. (2002). Arbitration in accordance with Law No. 27 of 1994 and International Arbitration Regulations, Don Publisher, pp. 95 et seq.

Al-Tahtawi, M. (1999). Arbitration in Civil and Commercial Materials and its Permissibility in Administrative Contract Disputes, no edition, New University Publishing House, Al- Alexandria, p 214.

Haddad, H. (2000). Supervision of Arbitration Rulings between Duality and Unity, Dar Al-Fikr Al-Jami` for Publishing, Alexandria, issue, 26 and beyond.

Hassan, A. (2001). Optional and Compulsory Arbitration in Civil and Commercial Disputes, University Thought House, Alexandria, pp.11.

Jamal, M., \& Okasha, A. (1998). Arbitration in International and Domestic Private Relations, Halabi Publications, Beirut, Vol. 1, pp.60

Shehata, M. (1993). Establishment of the Convention for the Judicial Authorities of the Arbitrators, pp. 15-19.

Tarawneh, M. (2001). The Reform of International Trade Law, An Analytical Study of the Law of International Trade, and its Relation to Private International Law, Dar Rand for Publishing and Distribution, 1st edition, p. 91.

Tarawneh, M. (2010). The Judicial Supervision of Arbitral Jurisdictions in Jordanian Law, Comparative Study (1st ed.). Da'ir Wael for Publishing, p. 43 et seq.

\section{Copyrights}

Copyright for this article is retained by the author(s), with first publication rights granted to the journal.

This is an open-access article distributed under the terms and conditions of the Creative Commons Attribution license (http://creativecommons.org/licenses/by/4.0/). 